\title{
Good Amil Governance in Yogyakarta: Psychological Approach
}

\author{
Zaki Abdullah and Duddy Roesmara Donna \\ Graduate School, Universitas Gadjah Mada \\ Dinda Aisyah Najmi \\ Faculty of Economics and Management, IPB University \\ Paper to be presented at International Conference of Zakat 2019 \\ 3-4 October, Universitas Padjadjaran, Bandung, Indonesia
}

\begin{abstract}
The implementation of Good Amil Governance as one of important aspects in standard of international zakat management institution that stated in Zakat Core Principles requires an approach that is more than just amil competence and qualification aspect. Psychological aspect of amil in work also needs to be considered in order to obtain and maintain the best human resources. As a profession that is oriented towards social benefits, amil has different working rhythm and consequences from profit institutions. This research aims to measure the happiness of amil in the workplace and see the impact on amil productivity. The result show that amil is a satisfying job, the most blissful factor for amil is work motivation, while the most unhappy factor for amil is unclear career path and less promising. In addition, the happiness level of amil also has positive relationship to the work productivity level of amil. Therefore, psychology condition of amil should be considered in order to increase the performance of zakat institutions.
\end{abstract}

Keywords: Amil Zakat, Good Amil Governance, Happiness, Productivity, Psychology JEL Classification: D23, D91

\section{INTRODUCTION}

Poverty and the gap of economic welfare are the problems of each country, therefore the poverty alleviation and gap of economic decrease indicators included in Sustainable Development Goals (SDGs) agenda that established by The United Nations as a development goals for human and earth benefit. Zakat becomes one of the right tools to reduce the poverty and gap of economic welfare (Beik, 2009). A study by Firdaus et al (2012) found that the potential of zakat in Indonesia reached 217 trillion rupiah or $3.4 \%$ of Indonesia's GDP in 2010. Then in 2019, research by BAZNAS (2019) shows that potential of zakat fund increased into 233,8 trillion rupiah. This zakat fund can serve as a tool to decrease the poverty and gap of economic.

According to Statistik Zakat Nasional (2017), the current collection of zakat 'remains' 6 trillion rupiah or $2.8 \%$ of existing potential. Therefore, there are still many tasks to be done by zakat institutions in digging the potential owned. As an effort to optimize the existing potential, zakat management should be well managed by competence and credible institutions. Beik et al (2016) provides the reference of Zakat Core Principles that is basic principles of zakat management as an effort by the zakat institutions to implement the ideal management zakat system.

One of the important principles of zakat institutions is Good Amil Governances aspect, it is because amil is the motor of the 
collecting system, administration and zakat distribution. This matter strengthened by Rusydiana \& Firmansyah (2017) in their research that put the Good Amil Governance as the most priority aspect in Supervision. This shows that this aspect is one of the considered principles in supporting the optimization of existing zakat potentials.

The implementation of Good Amil Governance can be conducted by implementing the following aspects: transparent, accountable, responsible, justice, benefits, sharia and local wisdom (Chotib et $a l, 2018)$. Therefore, it is necessary for professional and competence amil in accordance to the required field. However, in addition to the competency and professional factors of the amil, the psychological wellbeing in the implementation of Good Amil Governance also needs to be concern. In this regard, well-being has a broad meaning. The measurement of well-being using arranged indicators that not only to describe the condition of material prosperity (welfare), but also lead to the condition of subjective welfare or happiness (BPS, 2018).

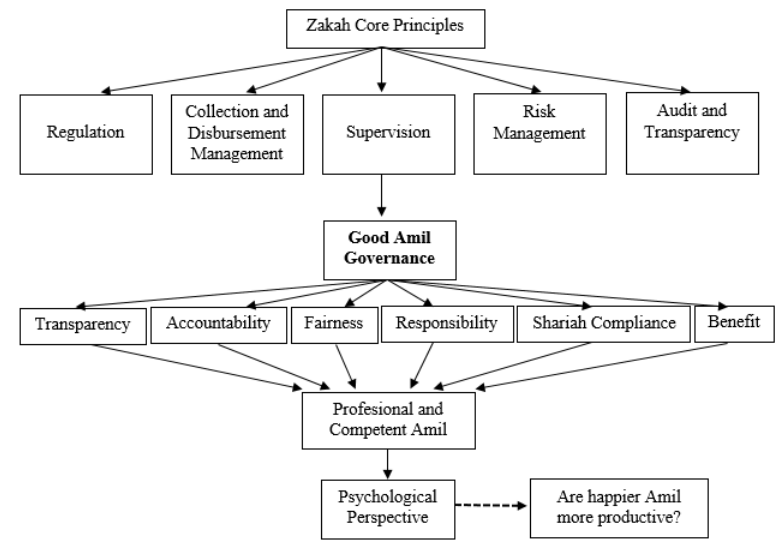

Figure 1. Framework of Thinking

\section{Literature Review}

In research conducted by (Sharifzadeh \& Almaraz, 2014) it was found that happy workers will tend to be more productive than those who are less happy. Workers also do not need to worry and can be focus on their work because all of their needs are met. In addition, amil that works with a feeling of happiness will be more total in working and loyal to the zakat institution where amil works.

Cadmus (2012) in his research found that among the factors that influence the happiness of worker (psychological wellbeing) is a right workload, work time and live a balanced life (work-life balance), decent salary, work environment with a positive colleagues and clear career path. Although happiness in workplace cannot be achieved continuously, but these factors need to be considered by a manager who manages human resources (HR), the target and productivity of the institution that will be achieved need to be determined realistically and wisely by looking at the aspects of the resources they have.

Work motivation will have a positive impact on commitment to an organization (Mangkunegara \& Octorend, 2015). Work motivation also has a positive effect on employee happiness, workers who are increasingly motivated and commited will work better and be satisfied (Sohail et al, 2014). As a non-profit social institution, zakat institution have different characteristics compared to profit orienteed-based companies, including in managing their own human resources. This is because there is no production or sales process in zakat institutions, but rather makes the collection of zakat fund as a factor of production, then channeling the fund to the mustahik in order to equalize social economics condition in the society. These different goals make the work motivation of employees at the zakat institution (amil) will also be different.

It can be concluded that the happiness of an amil in work is needed because the implementation of Good Amil Governance as one of the Zakat Core Principles agenda 
cannot be carried out without the support of amil psychological factors. Disorders of psychological factors have a negative effect on amil's performance and their professionalism. For example, due to inadequate financial factors, unclear career paths, less suitable work environment, heavy workload, tight work time and passion discrepancy of amil in the field of work.

\section{Objectives}

The psychological aspect of amil is an important variable in the institution of zakat, because the condition of amil as a motor of zakat institution will determine the productivity and achievement of the zakat institution. This research tries to look at the role and management of amil from a different perspective, which is related to psychology of amil in managing zakat funds.

Psychological well-being can be measured through the happiness of amil in the workplace, happiness can be measured through several latent variables. Thereby, there are 2 (two) objectives in this study namely:

1. Measuring happiness of amil in zakat institutions in Yogyakarta.

2. Measuring the impact of happiness of amil on work productivity.

\section{METHODOLOGY}

\section{Work Happiness Factors of Amil}

Happiness can be measured through several factors to describe amil satisfaction in working as workers in general. The happier person will make him more productive at work (Sgroi, 2015). Based on the principle of benefit on Good Amil Governance in the Zakat Core Principles, amil does not only have an orientation to work, but also charity under the zakat institution as a social organization at the same time. These factors can also illustrate the psychological side of the amil profession. The proxies of happiness of amil can be described by the following factors:

Table 1. Determinants of Happiness at Work

\begin{tabular}{|c|l|l|}
\hline No & $\begin{array}{l}\text { Determinants of } \\
\text { Worker Happiness }\end{array}$ & \multicolumn{1}{|c|}{ Reference } \\
\hline 1 & Workload & $\begin{array}{l}\text { (Cadmus, 2012), } \\
\text { (Shah } \text { et al, 2011) }\end{array}$ \\
\hline 2 & Career Path & $\begin{array}{l}\text { (Cadmus, 2012), } \\
\text { (SEEK Asia, 2017) }\end{array}$ \\
\hline 3 & $\begin{array}{l}\text { Financial } \\
\text { Welfare/Salary }\end{array}$ & $\begin{array}{l}\text { (Cadmus, 2012), } \\
\text { (SEEK Asia, 2017), } \\
\text { (Wulandari \& } \\
\text { Widyastuti, 2014) }\end{array}$ \\
\hline 4 & Work Motivation & $\begin{array}{l}\text { (Sohail } \text { et al, 2014), } \\
\text { (Mangunegara \& } \\
\text { Octorend, 2015) }\end{array}$ \\
\hline 5 & Work Environment & $\begin{array}{l}\text { (Cadmus, 2012), } \\
\text { (SEEK Asia, 2017), } \\
\text { (Wulandari \& } \\
\text { Widyastuti, 2014), } \\
\text { (Fernández } \text { et al, } \\
\text { 2017) }\end{array}$ \\
\hline 6 & Working Time & $\begin{array}{l}\text { (Cadmus, 2012), } \\
\text { (SEEK Asia, 2017), } \\
\text { (Fernández } \text { et al, } \\
\text { 2017) }\end{array}$ \\
\hline 7 & Passion & $\begin{array}{l}\text { (Spehar } \text { et al, 2016), } \\
\text { (Purba \& Ananta } \\
\text { 2018) }\end{array}$ \\
\hline
\end{tabular}

Types and Data Sources

The data used in this study is a primary data, it is obtained directly through field survey. Data retrieval method is conducted by filling out the administered questionnaires that have been made and processed by the researcher, the data in the questionnaire is ordinal data. Data was obtained from 46 respondents who were amil of zakat institutions in Yogyakarta. The selection of respondents is done through a purposive sampling method, which determines the respondent based on the provisions made by the researcher. Amil involved in this study came from 3 (three) 
official zakat institutions, namely BAZNAS Yogyakarta City, BAZNAS Yogyakarta Province and Dompet Dhuafa Yogyakarta.

\section{Analysis Method}

The data that obtained from primary source is processed by a validity test to determine the validity of question as a proxy that illustrate the happiness of amil, after that the reability test is conducted to determine the level of questionnare consistency. Furthermore, descriptive analysis is conducted to measure the happiness of amil in its working environtment, measuring scale is at the score range 1-5 where number 3 is neutral, the bigger the score then the amil is getting happier. While, Pearson Correlation Anaysis test is used to determine the relationship betweeen the happiness level of amil to the level productivity in work.

\section{RESULTS AND DISCUSSIONS}

\section{Validity and Reliability Test}

After the completion of questionnare, the validity test is conducted about the questions on the questionnare. There are 25 from 35 questions on the questionnare that fulfill the prerequisites to be said as a valid question where the 25 questions have r-count $>$ r-table based on the significant test at a real level of $5 \%$. While the other 10 questions are invalid because it has error level more than $0,05 \%$.

Table 2. Result of Validation Test

\begin{tabular}{|c|l|c|c|c|}
\hline Item & Indicator & $\begin{array}{c}\text { Correlation } \\
\text { Coeff. }\end{array}$ & r-table & Conclusion \\
\hline X1.1 & $\begin{array}{l}\text { Work } \\
\text { Motivation }\end{array}$ & 0,746 & 0,444 & Valid \\
\hline X1.2 & $\begin{array}{l}\text { Work } \\
\text { Motivation }\end{array}$ & 0,492 & 0,444 & Valid \\
\hline X1.3 & $\begin{array}{l}\text { Work } \\
\text { Motivation }\end{array}$ & 0,493 & 0,444 & Valid \\
\hline X1.4 & $\begin{array}{l}\text { Work } \\
\text { Motivation }\end{array}$ & 0,714 & 0,444 & Valid \\
\hline
\end{tabular}

\begin{tabular}{|c|l|c|c|c|}
\hline Item & Indicator & $\begin{array}{c}\text { Correlation } \\
\text { Coeff. }\end{array}$ & r-table & Conclusion \\
\hline X2.1 & $\begin{array}{l}\text { Working } \\
\text { Time }\end{array}$ & 0,673 & 0,444 & Valid \\
\hline X2.2 & $\begin{array}{l}\text { Working } \\
\text { Time }\end{array}$ & 0,490 & 0,444 & Valid \\
\hline X2.3 & $\begin{array}{l}\text { Working } \\
\text { Time }\end{array}$ & 0,528 & 0,444 & Valid \\
\hline X3.1 & $\begin{array}{l}\text { Work } \\
\text { Environment }\end{array}$ & 0,676 & 0,444 & Valid \\
\hline X3.2 & $\begin{array}{l}\text { Work } \\
\text { Environment }\end{array}$ & 0,577 & 0,444 & Valid \\
\hline X3.3 & Work & 0,578 & 0,444 & Valid \\
\hline X4.1 & Workload & 0,763 & 0,444 & Valid \\
\hline X4.2 & Workload & 0,521 & 0,444 & Valid \\
\hline X4.3 & Workload & 0,809 & 0,444 & Valid \\
\hline X5.1 & Career Path & 0,728 & 0,444 & Valid \\
\hline X5.2 & Career Path & 0,696 & 0,444 & Valid \\
\hline X5.3 & Career Path & 0,562 & 0,444 & Valid \\
\hline X5.4 & Career Path & 0,602 & 0,444 & Valid \\
\hline X6.1 & Passionate & 0,513 & 0,444 & Valid \\
\hline X6.2 & Passionate & 0,694 & 0,444 & Valid \\
\hline X6.3 & Passionate & 0,723 & 0,444 & Valid \\
\hline X7.4 & Passionate & 0,796 & 0,444 & Valid \\
\hline X7.1 & Salary & 0,717 & 0,444 & Valid \\
\hline X7.2 & Salary & 0,684 & 0,444 & Valid \\
\hline X7.3 & Salary & 0,590 & 0,444 & Valid \\
\hline X7.4 & Salary & 0,665 & 0,444 & Valid \\
\hline & & & & \\
\hline
\end{tabular}

Source : processed data by Author (2019)

After the validity test, the reliability test is conducted of all variable that considered valid, the validity test is conducted to test the consistency of the questionnare. Rule of thumb of alpha value or composite reliability should be bigger than 0,7 although 0,6 is still acceptable (Hair et al dalam Putri \& Gunawan, 2014). The result of the processing data for reability test of the 25 valid questions show that the questionnare is highly reliable as seen in Table 3 below.

Table 3. Result of Reliability Test

\begin{tabular}{|c|c|}
\hline Cronbach's Alpha & Number of Statement \\
\hline 0.945 & 25 \\
\hline
\end{tabular}

Source : processed data by Author (2019) 
Croncbach's Alpha 0,945 value shows that the 25 questions on the used questionnare have a fairly high degree of reliability. After a validity and reliability test, an analysis of the respondents' answer can be conducted.

\section{Amil's Happiness at Work Analysis}

The result of a descriptive analysis that obtained from the average of respondents' answer score showed that the career path found in the related zakat institutions are currently the factor that make amil least happy with the lowest happiness score in among other factors that is 3,78. This is because the majority of amil in related zakat institution is contracted amil, where amil is not a permanent occupation. The permanent amil in each institution only amounted 5-10 people, because that the owned human resources (HR) can be changed in a short time, this gives a risk to the zakat institution because the quality of an employee will improved with a clear career path (Dewi \& Utama, 2016). Beside the impermanent occupasion factor of amil, the career path in the zakat institution itself is unclear and less promising.

Although the zakat institution is a charity and non-profit institution, the zakat funds still need to be managed professionally. Therefore, amil as a zakat funds manager need to have adequate qualifications and loyalty to the zakat isntitution. If amil is turnovered in a short time because the offeref career path is less interesting or even none at all, that situation will weaken the zakat institution HR strength. The career path in zakat institutions must be made in different from those in the company or civil servant.

The next low happiness factor after career path is workload with a score of 4 . The currently workload in related zakat institution is less enjoyed by the amil. Hence, the workload given by the zakat institution is subjectively perceived by amil above the standard. Workload can encourage employee productivity, but excessive workloads will result in a bad impact in the form of physical or mental fatigue (Irawati \& Carolina, 2017).

After the career paths and workloads, the next factor that give contribution to the happiness of amil is passion based on the relationship between the desires and abilities owned by amil and the current field of work. The measurement result for this factor have a score of 4.02, this score can be said to be quite good, meaning that currently amil in related zakat institution have a match field of work and passionate with it such as in administration, finance, fundrising, management or services. Nevertheless, there is an important note in one of the statements as a proxy for the passion of work which is related to the desired job. On the average, the respondents answered that they were not sure that amil was the profession they wanted or aspired to.

Another factor that measures happiness of amil is the financial factor or salary obtained as an amil. The measurement results show that the salary of a job as amil has a score of 4.03 , which can be said that amil in the related zakat institution is quite happy with the salary that they earned currently. Based on the results of interviews in the field, the average salaries of the amil certainly not as big as in companies or other profit institutions. Indeed, zakat institutions are non-profit institutions that are not profitoriented but they were social institutions that serve the community, especially who need help. However, the salary they earn is in accordance the work they done. The amount of their income is above the regional minimum wage, it can fulfill daily needs and has a fair payroll system.

The work environment is also one of the factors that can be utilized to measure the happiness of the work of amil, the work environment found in zakat institutions in Yogyakarta is fairly good and gives a sense 
of happiness to the amil with a score of happiness 4,30. This score is much better than the four previous factors, it is means that the amil in zakat institutions in Yogyakarta are happy with the conditions of the existing work environment. A good work environment is one that supports employees to work productively but not under pressured by colleagues or superiors. The colleagues in workplace also support each other and do not overturn each other's work. Good quality standards also must be applied to keep the work environment productive and professional, zakat institutions in Yogyakarta have implemented this. This condition is reflected in the amil's happiness score by work environment factor of 4,30 .

Two other factors that have been good for the work happiness of amil in zakat institutions in Yogyakarta are the factors of working time and work motivation. The office hours that are not too tight and ideal ( 8 hours of work), amil is given proportional time for vacation and leave by the institution. The policy about the standard of working hours and overtime is in accordance with Rule of Law No. 13 of 2003 about Manpower. Furthermore, the amil can enjoy working moments and daily work can be completed on time. The happiness score for working time factor is 4,45 .

The last factor is work motivation, it has the highest score as a happiness factor of an amil zakat in Yogyakarta with a score of 4,46 . This is because the motivation as an amil is aimed at helping people in need and amil is a noble profession as Allah mentioned in the Qur'an Chapter 9 (Surah At-Taubah) verse 60 . Amil is a noble profession because it is glorified by Allah. The score of happiness based on this high working motivation shows that the amil are the ones who have a high social spirit and a good level of spirituality. Based on the work motivation they had, the amil feel happy even though not necessarily amil is the desired or aspired profession.

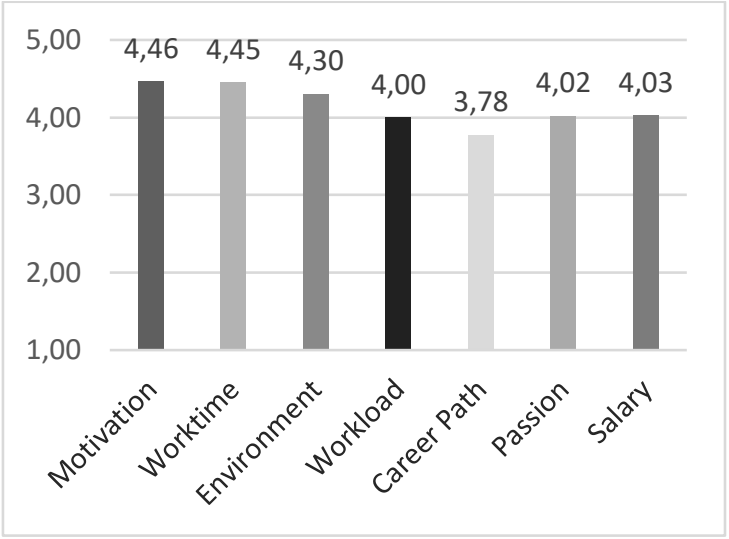

Figure 2. Level of Amil Happiness by Determinants

Based on the seven factors as a means of measuring the work happiness of amil in Yogyakarta above, then an average score of 4,15 is obtained. The score shows that the profession of amil is a satisfying job and this means they are happy, happiness which not only covers the needs of the material, but also non-material such as the needs of spirituality, social and suitability in the field of work. However, there are still records that zakat institution can do to increase the happiness of amil which is to improve career and development path of the amil.

\section{The Relationship between Work Happiness and Productivity of Amil}

After knowing the level of work happiness of amil, then the next step is measure the relationship between work happiness to the productivity of amil. The measure test is based on research conducted by (Sharifzadeh \& Almaraz, 2014) dan (Sgroi, 2015) which found that happy workers will tend to be more productive at work.

The result of the descriptive analysis of from the questionnaire data indicate that each happiness factor has different contributions to the level of amil 
productivity. As with the level of happiness work motivation factors has the greatest contribution to amil productivity with a score of 4,50. This is because the work motivation factor encourages someone to work better while they enjoy the job. The happiness of amil as a result of the work motivation factor has a high score, therefore it is natural when the work motivation occupies the highest position in influencing productivity.

Furthermore, the happiness factor which has the biggest contribution to amil productivity after work motivation is working time and working environment with same score of 4,40. Then followed by a passion in field of work with score of 4,30, the salary earned with score of 4,20 and the workload with score of 4,10. While the happiness factor that affects productivity with the lowest score is the career path with score of 3,75. As the level of happiness, the contribution of career path in the zakat institutions makes amil feel unhappy, which results in poor productivity. Overall, the amil agree that the happiness factor is one of the factors that affect their productivity. This is indicated by the average score of 4,22 which states that each happiness factor has an impact on their work productivity.

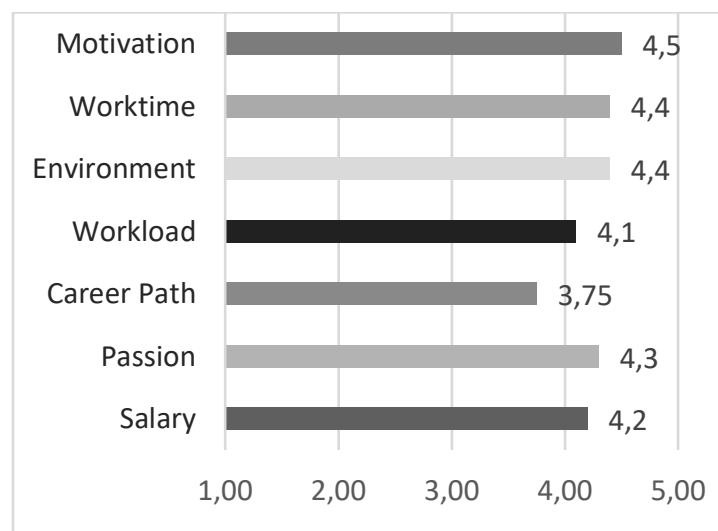

Figure 3. The Amount of Each Factor Contribution to Amil Productivity

To find out the relationship between happiness and productivity level of amil, a correlation analysis between each happiness factor was carried out with the amount of its contribution to productivity.

Table 4. Correlation Analysis between Happiness and Productivity of Amil

\begin{tabular}{|c|c|}
\hline Correlation Value & $\begin{array}{c}\text { Productivity } \\
\text { Level of Amil }\end{array}$ \\
\hline Happiness Level of Amil & 0,899 \\
\hline Number of Variable (N) & 7 \\
\hline
\end{tabular}

The result of the Pearson correlation analysis give a value of 0,899 as seen in Table 4. These results indicate that there is a strong relationship between happiness and productivity level of amil. Therefore, even though amil is a satisfying profession, the determinants of happiness of the amil need to be continuously improved in order to increase the productivity of amil, especially in improving career paths and providing workload.

\section{CONCLUSION}

The amil of zakat in Yogyakarta already feels happiness in working at the workplace, the most blissful factor for amil is work motivation. The work motivation is the perception that amil is a noble profession in Islamic teachings and also aimed to help people in need through zakat fund, it can be also concluded that the majority of amil had a high spirituality and social sensitivity. Besides, the most unhappy factor is a career path that is unclear and less promising, this factor could be demotivating amil at work and reducing the loyalty of amil into zakat institutions, even though amil competencies and qualifications will increase over time. In order to keep and maintain the good amil, it is necessary to have a clear and promising carrer path map that including material things such as financial and position and non- 
material things such as the scope of social contributions and flexibility time to work.

The level of work happiness of amil also has a positive relationship to the level of work productivity. Happier amil tend to be more productive at work. Therefore, the psychological conditions of amil need to be concerned and maintained in order to improve the performance of zakat institutions, especially in the aspects of the implementation of Good Amil Governance in terms of human resources. Further research studies on similar field can also be conducted in other regions and countries.

\section{REFERENCES}

Badan Amil Zakat Nasional. 2018. Statistik Zakat Nasional 2017. Juni. BAZNAS Republik Indonesia. Jakarta.

Badan Amil Zakat Nasional. 2019. Indikator Pemetaan Potensi Zakat. Juli. BAZNAS Republik Indonesia. Jakarta.

Badan Pusat Statistik. 2017. Indeks Kebahagiaan 2017. Desember. BPS Republik Indonesia. Jakarta.

Beik, I.S. 2009. "Analisis Peran Zakat dalam Mengurangi Kemiskinan : Studi Kasus Dompet Dhuafa Republika". Jurnal Pemikiran dan Gagasan 2(1): 1-11.

Beik, I.S. 2014. "Toward an Establishment of an Efficient and Sound Zakat System: Proposed Core Principles for Effective Zakat Supervision". Disajikan dalam Working Group of Zakat Core Principles 2014.

Cadmus, F. 2012. Happiness at Work: Rules for Employee Satisfaction and Engagement. Dalam Trends. Editor Philip C. Berwick, New York: William S. Hein \& Co., Inc.

Chotib, M., Yuswadi, H., Toha A. dan Wahyudi, E. "Implementation of Good Amil Governance At Amil Zakat Institution". International Journal of
Humanities and Social Science Invention 7(1): 93-100.

Dewi, N.L.P.A.A. dan Utama, I.W.M. 2016. "Pengaruh Pengembangan Karir terhadap Kinerja Karyawan melalui Mediasi Motivasi Kerja pada Karya Mas Art Gallery". E-Jurnal Manajemen Unud 5(9): 5494-5523.

Fernández, J.L.F., Gamez, M.A.F., Aragón, N.D.Q. dan Gil, A.C. "Happiness at Work, Business Behaviour, and Worker Perceptions: A Case Study. Ramon Llull Journal of Applied Ethics (8): 33-64.

Firdaus, M., Beik, I.S. dan Irawan T. "Economic Estimation and Determinations of Zakat Potential in Indonesia". IRTI Working Paper Series. Islamic Development Bank. 9 Oktober. Jeddah.

Irawati, R. dan Carollina, D.A. 2017. "Analisis Pengaruh Beban Kerja terhadap Kinerja Karyawan Operator pada PT Giken Precision Indonesia". Inovbiz: Jurnal Inovasi dan Bisnis 5(1): 51-58.

Mangkunegara, A.P. dan Octorend, T.R. 2015. "Effect of Work Discipline, Work Motivation and Job Satisfaction on Employee Organizational Commitment in the Company (Case Study in PT. Dada Indonesia)". Universal Journal of Management 3(8): 318-328.

Pemerintah Indonesia. 2003. Undangundang No. 13 Tahun 2003 tentang Ketenagakerjaan. Lembaran Negara Republik Indonesia Tahun 2003, No. 39. Jakarta: Sekretariat Negara.

Purba, S.D. dan Ananta, A.N.D. 2018. "The Effects of Work Passion, Work Engagement and Job Satisfaction on Turn Over Intention of The Millennial Generation". Jurnal Manajemen Dan Pemasaran Jasa 11(2): 263-274. 
Putri, A.A. dan Gunawan, W. 2014. "Uji Validitas dan Reliabilitas Life Value Inventory". Jurnal NOETIC Psychology 4(2): 181-196.

Rusydiana, A.S. dan Firmansyah I. 2017. "Prioritizing Zakat Core Principles (ZCP) Criteria". Esensi: Jurnal Bisnis Dan Manajemen 7(2): 277-302.

Seek Asia. 2017. Employee Job Happiness Index 2017. Desember. Seek Asia Signature Market Research. Hongkong.

Sgroi, D. 2015. "Happiness and Productivity: Understanding the Happy-Productive Worker". SMF-CAGE Global Perspective Series. October. UK.

Shah, S.S.H., Jaffari, A.R., Aziz, J., Ejaz, W., Ul-Haq, I. dan Raza, S.R. 2011. "Workload and Performance of Employees". Interdisciplinary Journal of Contemporary Research in Business 3(5): 256-267.

Sharifzadeh, M. dan Almaraz, J. 2014. "Happiness and Productivity in the Workplace". American Journal of Management 14(4): 19-26.

Sohail, A., Safdar, R., Saleem, S., Ansar, S. dan M. Azeem. 2014. "Effect of Work Motivation and Organizational Commitment on Job Satisfaction: (A Case of Education Industry in Pakistan)". Global Journal of Management and Business Research: A 14(6): 41-46.

Spehar, I., Forest, J., Stenseng, F. 2016. "Passion for Work, Job Satisfaction, and the Mediating Role of Belongingness". Scandinavian Journal of Organizational Psychology 8(1): 1726.

Wulandari, S. dan Widyastuti, A. 2014. "Faktor - Faktor Kebahagiaan Di Tempat Kerja". Jurnal Psikologi 10(1): 49-60.
Zaki Abdullah

Graduate School of Universitas Gadjah Mada

zaki.abdullah@mail.ugm.ac.id

Dinda Aisyah Najmi

Faculty of Economics and Management IPB University

dindaaisy@apps.ipb.ac.id

Duddy Roesmara Donna

Graduate School of Universitas Gadjah Mada

duddy@ugm.ac.id 